\title{
The significance of sheeted dike complexes in ophiolites
}

Paul T. Robinson, John Malpas, Dept. of Earth Sciences, The University of Hong Kong, Pokfulam Road, Hong Kong; Yildirim Dilek, Dept. of Geology, Miami University, 114 Shideler Hall, Oxford, Ohio 45056, USA; and Mei-fu Zhou, Dept. of Earth Sciences, The University of Hong Kong, Pokfulam Road, Hong Kong

\begin{abstract}
Sheeted dike complexes, in which dike intrudes dike without intermediate screens of gabbro or pillow lava, have long been considered key features of oceanic lithosphere and ophiolites formed in extensional environments. The presence of a sheeted complex implies an approximate balance between spreading rate and magma supply, such that there is just enough melt to fill newly formed fractures produced by spreading. Such a balance appears to exist at mid-ocean ridges, where both the spreading rate and magma supply are probably linked to mantle convection, and thus sheeted dikes appear to be a major part of the ocean crust. In contrast, ophiolites, which are formed or modified in suprasubduction zone environments, rarely have large, well-developed sheeted dike complexes, because magma supply and spreading rate are not linked in the same way. In suprasubduction zone environments, the spreading rate is controlled largely by the rate of slab rollback, whereas the magma supply is controlled by the local temperature profile, the lithology of the subducting crust and mantle wedge, the history and degree of melting of the mantle source, and the abundance and nature of fluids. Because spreading rate and magma supply are rarely balanced in these environ-
\end{abstract}

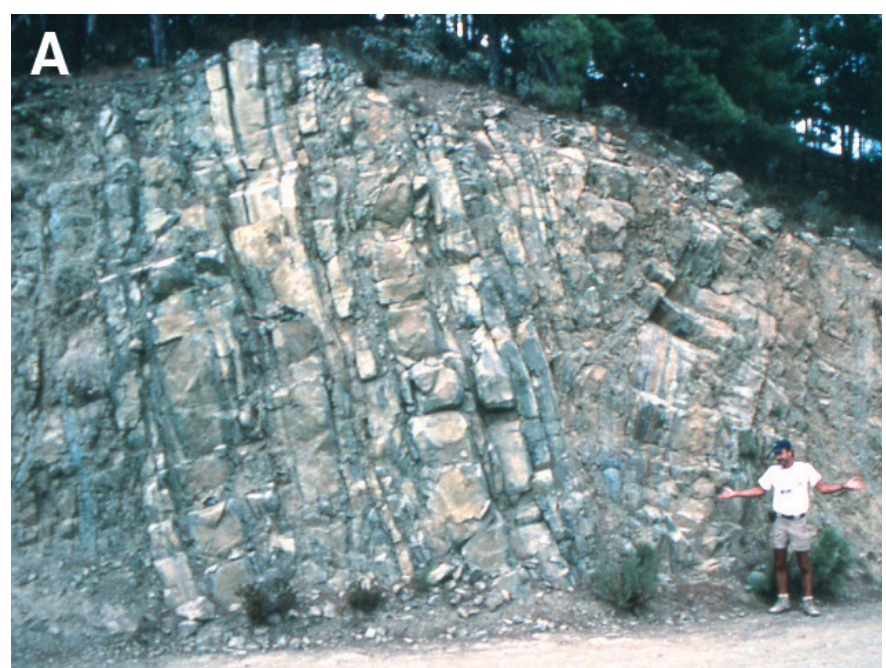

ments, we suggest that sheeted dikes, rather than being key elements of ophiolites, may instead be unusual features in such bodies. Thus, care must be exercised in using ophiolites to investigate spreading processes at mid-ocean ridges.

\section{INTRODUCTION}

Ophiolites are fragments of oceanic crust and upper mantle that have been uplifted and emplaced on continental margins or in accretionary prisms and island arcs. According to a 1972 GSA Penrose Conference, an idealized, complete ophiolite contains, from the base upward, mantle peridotites, layered ultramafic rocks and gabbros, isotropic gabbros, a sheeted dike complex, and an extrusive sequence, composed of pillowed and massive lavas, overlain by radiolarian chert and/or pelagic limestone (Anonymous, 1972; Dilek, 2003). The presence of a sheeted dike complex has been interpreted as an essential component of ophiolites, as exemplified by the Troodos ophiolite of Cyprus (Fig. 1A), where such complexes were first recognized (Gass, 1968). Sheeted dikes, which are tabular intrusions of magma with no intervening screens of other host rock (Fig. 1B), are believed to form in extensional environments where the faults and fractures produced by seafloor spreading are filled with new magma flowing laterally and vertically along a narrow axial zone beneath the spreading center (Vine and Matthews, 1963; Gass, 1968; Kidd and Cann, 1974; Dilek et al., 1998). In 1968, when Gass correctly identified the sheeted complex in Troodos, mid-ocean ridges were the only environment where such spreading was known to occur; thus, he suggested a mid-ocean ridge environment for the formation of this ophiolite.

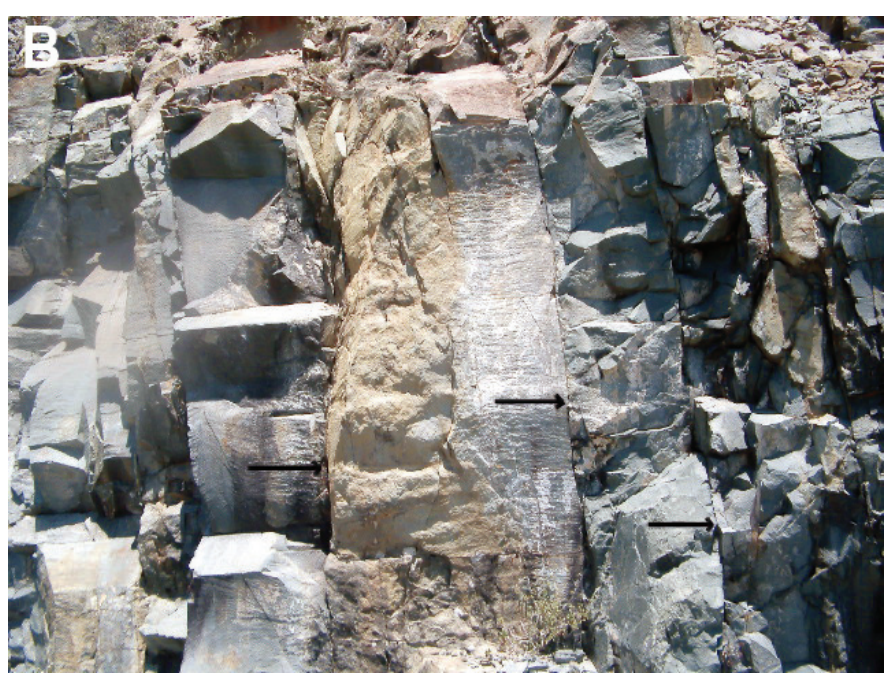

Figure 1. Sheeted dikes of the Cretaceous Troodos ophiolite, Cyprus. (A) A typical outcrop of sheeted dikes in which dike intrudes dike with no intervening host rock. Individual dikes range from a few centimeters to $\sim 0.5 \mathrm{~m}$ in this outcrop (Baragar et al., 1989). Note the inclined dikes on the right side of the picture. These earlier dikes were probably tilted by listric faulting along the spreading axis (Varga and Moores, 1985) and then intruded by the younger vertical dikes in the center. (B) Close-up view of sheeted dikes in Troodos showing contact relationships. Arrows point to one-sided chilled margins. 
Sheeted dikes similar to those in ophiolites have since been observed in the walls of oceanic fracture zones (e.g., at Hess Deep; Stewart et al., 2002, 2003) and have been drilled at DeepSea Drilling Project-Ocean Drilling Project (DSDP-ODP) Hole 504B south of the Costa Rica Rift (e.g., Alt et al., 1996; Bach et al., 1996; Dilek et al., 1996; Dilek, 1998). Although not widely exposed on the seafloor, such dikes are believed to be a major component of the ocean crust, forming the lower part of seismic layer 2 and perhaps the upper part of layer 3 (Detrick et al., 1994), where they are interpreted to form the plumbing system between sub-rift magma chambers and the overlying extrusive rocks.

Oceanic lithosphere is produced at different rates along modern spreading centers, leading to different structural architectures (Karson, 1998). Fast-spreading mid-ocean ridges are generally characterized by a voluminous magma supply and have well-defined convex axial highs, whereas slow-spreading ridges have a lower magma supply and are characterized by axial grabens and extensive tectonic disruption (Phipps Morgan et al., 1994; Cannat et al., 1995). Based on these observations, many workers have interpreted ophiolite complexes in the same manner. Thus, well-developed sheeted complexes showing little tectonic disruption have been interpreted as the products of fast-spreading centers, whereas poorly developed complexes with extensive disruption were thought to have formed at slow-spreading ridges (e.g., Nicolas et al., 1999).

We suggest that such a generalization is probably not valid and that direct correlations between in situ oceanic lithosphere and ophiolites are rarely possible. Although probably well developed in modern ocean crust, sheeted dikes are rare in ophiolites. Large, well-developed sheeted complexes are found only in a few bodies, such as the Troodos ophiolite of Cyprus (Gass, 1968; Baragar et al., 1989), the Semail ophiolite of Oman (Searle and Cox, 1999; Umino et al., 2003), the Kizildag ophiolite of Turkey (Dilek and Thy, 1998), and examples from Newfoundland (Church and Riccio, 1974; Strong and Malpas, 1975); most other ophiolites lack sheeted dikes entirely or contain only small, discontinuous bodies. Some ophiolites contain sill complexes rather than dikes (Hopson et al., 2008). The paucity of sheeted dikes in many ophiolites implies either that they did not form originally as part of the ancient oceanic lithosphere or that they were selectively removed during tectonic disruption of the crust, either during seafloor spreading or during ophiolite emplacement. However, ophiolites that lack sheeted dike complexes commonly have the other characteristic lithologies included in the Penrose Conference (Anonymous, 1972) definition, such as ultramafic rocks, gabbros, lavas, and pelagic-hemipelagic sedimentary rocks, and display no significant strain associated with emplacement tectonics. Because it is difficult to envisage the widespread, selective tectonic removal of the portion of an ophiolite that originally existed between the volcanic and plutonic rocks, we suggest that well-developed sheeted dike complexes rarely form in such bodies because the tectonic environment of formation of many ophiolites is different from that of mid-ocean ridges.

In this paper, we discuss the evidence for the formation of ophiolites in suprasubduction zones, consider the processes involved in the development of sheeted dikes, and show why such complexes are rare in ophiolites. We suggest that sheeted dikes, rather than being considered necessary elements of ophiolites, should be viewed as possible-but not essentialfeatures in such bodies.

\section{FORMATION AND EMPLACEMENT OF OPHIOLITES}

Increasingly detailed tectonic and geochemical studies over the past 30 years have shown that most ophiolites contain volcanic and plutonic rocks with clear suprasubduction zone geochemical signatures (Pearce, 2003, and references therein). For example, ophiolitic lavas are dominated by arc tholeiites, backarc basalts, andesites, dacites, and depleted lavas resembling boninites, most of which are distinctly different from mid-ocean ridge and ocean island basalts (Table 1) and are found only in modern suprasubduction zone environments. Some tholeiitic basalts erupted in suprasubduction zone environments have major oxide contents similar to those of mid-ocean ridge lavas but can easily be distinguished on the basis of their trace element compositions (Fig. 2). Compared to typical mid-ocean ridge basalt (MORB), suprasubduction zone magmas are characterized by significant enrichment in large ion lithophile elements (LILE: K, Rb, Cs, Th) and light rare earth elements (LREE) (Pearce, 1982) and depletion in high field strength elements (Ti, Nb, Ta, Hf) (Pearce, 1982; Shervais, 1982). Island arc basalts, for example, are easily recognized on mantle-normalized trace element spider diagrams by their marked negative $\mathrm{Nb}$ and $\mathrm{Ta}$ anomalies (Fig. 2). Many ophiolites also contain high $\mathrm{MgO}-$ high $\mathrm{SiO}_{2}$ lavas, such as boninites, that in modern environments are restricted to forearc regions.

A few rare occurrences of lavas with arc signatures are currently being erupted at modern ridge axes, such as in the Woodlark Basin (Perfit et al., 1987) and on the southern Chile Ridge (Klein and Karsten, 1995; Karsten et al., 1996); however, these are anomalous features in the ocean basin. The arc-like lavas being erupted in the Woodlark Basin are due to subduction reversal, so that seafloor spreading is now taking place in what used to be a backarc basin above a subduction zone dipping SW beneath the Solomon islands (Abbott and Fisk, 1986; Johnson et al., 1987). The collision of the Ontong Java Plateau with this subduction zone at about the middle or late Miocene halted the subduction and caused a subduction jump and polarity reversal beneath the Solomon Islands (Weissel et al., 1982). The southern Chile Ridge is being subducted beneath

Table 1. Average compositions of common oceanic basaltic rocks

\begin{tabular}{lcccccc}
\hline \hline & N-MORB & E-MORB & OIB & Alk-Oliv & Arc Thol & Bon \\
\hline $\mathrm{SiO}_{2}$ & 50.4 & 51.2 & 49.2 & 47.6 & 51.7 & 53.6 \\
$\mathrm{TiO}_{2}$ & 1.36 & 1.69 & 2.57 & 3.23 & 1.36 & 0.26 \\
$\mathrm{Al}_{2} \mathrm{O}_{3}$ & 15.2 & 16 & 12.8 & 15.7 & 16.57 & 13.5 \\
$\mathrm{FeOt}$ & 9.31 & 8.46 & 11.4 & 13.4 & 8.4 & 8.6 \\
$\mathrm{MnO}$ & 0.18 & 0.16 & 0.17 & 0.19 & 0.16 & 0.15 \\
$\mathrm{MgO}$ & 9 & 6.9 & 10 & 5.6 & 6.6 & 10.2 \\
$\mathrm{CaO}$ & 11.4 & 11.5 & 10.8 & 7.9 & 10.8 & 12.2 \\
$\mathrm{Na}_{2} \mathrm{O}$ & 2.3 & 2.7 & 2.1 & 4.0 & 3.0 & 0.92 \\
$\mathrm{~K}_{2} \mathrm{O}$ & 0.09 & 0.4 & 0.5 & 1.5 & 0.34 & 0.41 \\
$\mathrm{P}_{2} \mathrm{O}_{5}$ & 0.14 & 0.15 & 0.25 & 0.35 & 0.18 & 0.04 \\
$\mathrm{Total}$ & 99.38 & 99.16 & 99.79 & 99.47 & 99.11 & 99.88 \\
\hline
\end{tabular}

Note: N-MORB — normal mid-oceanic ridge basalt; E-MORB — enriched mid-oceanic ridge basalt; OIB - oceanic island basalt; Alk-Oliv-alkaliolivine basalt; Arc Thol-arc tholeiitic basalt; Bon-boninite. 


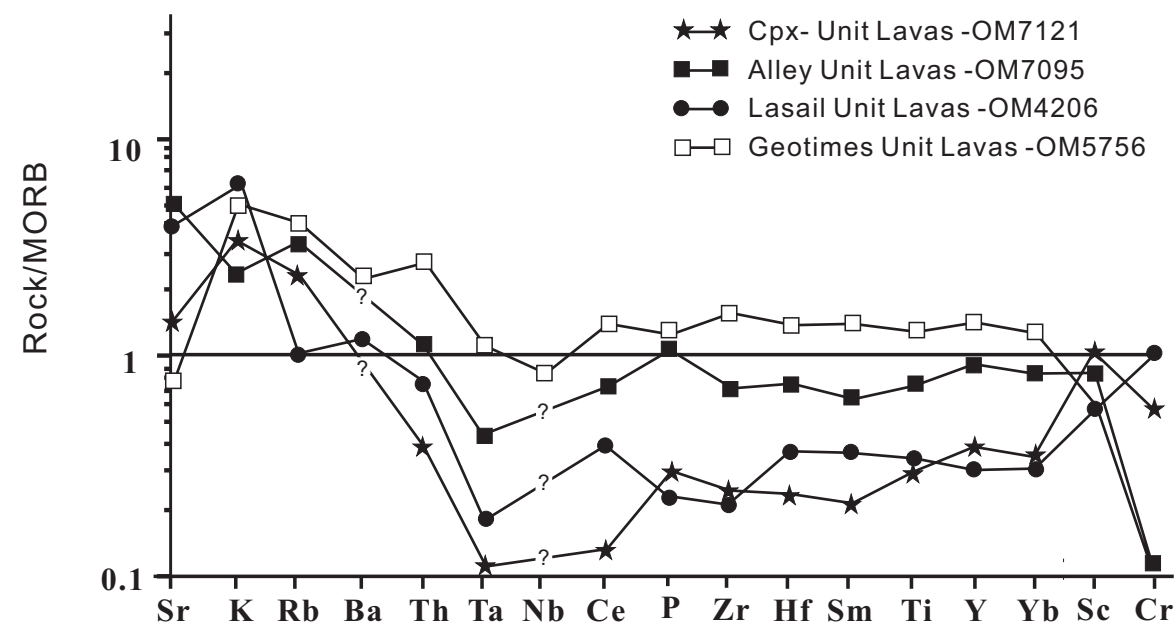

B

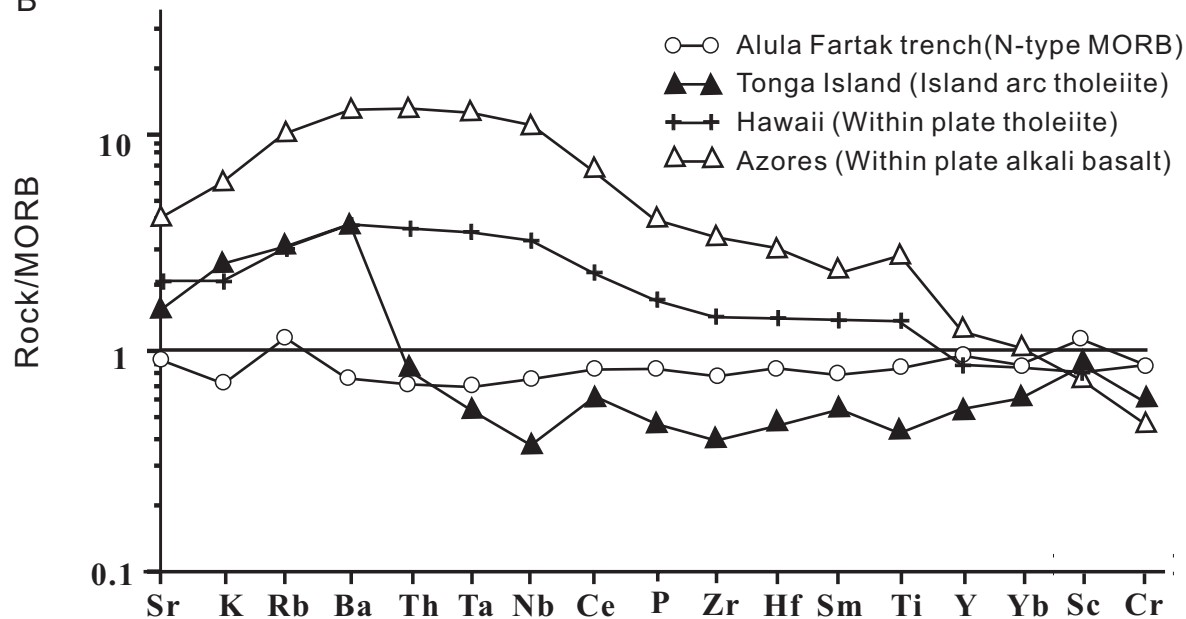

Figure 2. Mid-ocean ridge basalt (MORB)normalized trace element diagrams comparing lavas of the Cretaceous Oman ophiolite to those of modern oceanic environments (after Alabaster et al., 1982). Only lavas of the oldest Geotimes unit of the Oman ophiolite have compositions similar to MORB, but even these are enriched in large ion lithophile elements, such as $\mathrm{Ba}, \mathrm{K}$, and $\mathrm{Rb}$ (Fig. $2 \mathrm{~A}$ ), indicating subduction influence. The other units compare closely with island arc tholeiites of the Tonga Islands in the SW Pacific (Fig. 2B), which are characterized by negative $\mathrm{Nb}$ and $\mathrm{Ta}$ anomalies. The Oman volcanic rocks look distinctly different from other within-plate type ocean island basalts. Most other ophiolites show suprasubduction zone geochemical signatures comparable to the Oman ophiolite. $\mathrm{N}$-type MORB - normal MORB. the South American continent, and this process may account for the anomalous trace element signatures (i.e., weak $\mathrm{Nb}$ anomaly, slight enrichment of LILE) and modest variations in the $\mathrm{Pb}, \mathrm{Sr}$, and $\mathrm{Nd}$ isotope ratios (consistent with contamination of its mantle source by subducted terrigenous sediment and altered oceanic crust) of the erupted lavas (Sturm et al., 2000).

These isolated examples cannot explain the widespread occurrence of suprasubduction zone lavas in ophiolites. For example, the Troodos ophiolite of Cyprus, long considered to be a fragment of normal oceanic lithosphere, contains only arc tholeiites, andesites, dacites, and rhyodacites accompanied by boninitic lavas (Robinson et al., 1983; McCulloch and Cameron, 1983; Malpas and Langdon, 1984; Robinson and Malpas, 1990; Bednarz and Schmincke, 1994; Dilek and Flower, 2003); the Oman ophiolite contains a range of lava compositions, most with suprasubduction zone signatures (Alabaster et al., 1982; Ishikawa et al., 2002), and the rocks of the Bay of Islands ophiolite of Newfoundland have trace element signatures typical of suprasubduction zone environments (Jenner et al., 1991; Suhr and Edwards, 2000).
Some ophiolites also contain remnants of volcanic and plutonic rocks comparable to those found in modern ocean crust, suggesting a compound origin (e.g., Shervais and Kimbrough, 1985; Batanova and Sobolev, 2000; Zhou et al., 2000; Malpas et al., 2003). In such cases, it is generally postulated that fragments of oceanic lithosphere that formed originally at midocean ridges were trapped above intraoceanic subduction zones, where they were invaded by, reacted with, and partially replaced by, suprasubduction zone melts (Dilek and Flower, 2003; Malpas et al., 2003). In other cases, such as in the Coast Range ophiolite of California and the Josephine ophiolite of Oregon, MORB lavas intrude suprasubduction rocks, possibly as the result of ridge collision and/or rift propagation into an arc or forearc region (Shervais et al., 2004; Harper, 2003). However, it is now generally accepted that the majority of ophiolites are both formed and emplaced in suprasubduction zone environments (e.g., Stern and Bloomer, 1992; Shervais, 2001; Pearce, 2003).

Moores (1982) classified ophiolites into Cordilleran and Tethyan types (now referred to as Sierran and Mediterranean types, 
respectively-see Dilek, 2003) based on their emplacement mechanisms. Sierran-type ophiolites occur in accretionary-type orogenic belts where they structurally overlie subductionaccretion complexes and are incorporated into active continental margins through the growth and uplift of the underlying accretionary prisms. Mediterranean ophiolites structurally overlie passive continental margins and micro- and ribbon continents and are emplaced by partial subduction of these buoyant crustal entities beneath them. Ophiolites that evolved in restricted Mediterranean-type marginal basins may have a typical Penrose Conference-type (Anonymous, 1972) pseudostratigraphy, and the time difference between their igneous accretion and tectonic emplacement is commonly short, perhaps >10 m.y. (Dilek et al., 2005). In contrast, Sierran-type ophiolites are believed to have formed in active margins facing large ocean basins, such as the modern western Pacific region, where continuous subduction persisted for prolonged periods. Such ophiolites display a highly heterogeneous internal structure with igneous ages spanning 50 m.y. or more. However, many of these differences may simply reflect different stages of evolution of the ophiolites rather than fundamental differences in their formation. What is apparent is that most Sierran-type ophiolites lack sheeted complexes entirely; others may have isolated dike swarms or small enclaves of sheeted dikes (Dilek et al., 1991; Beccaluva et al., 2004). Sheeted dikes are commonly better developed in Mediterranean-type ophiolites, but even in these bodies, large, well-developed sheeted complexes, such as those observed in Cyprus and Oman, are rare. Why do sheeted dikes occur in some ophiolites and not in others, and why are such complexes rare?

\section{SPREADING VERSUS MAGMA SUPPLY RATES IN OCEANIC CRUST FORMATION}

Sheeted dikes form when magma is intruded into cracks and fissures produced by tensile stresses. These magma-filled fractures propagate vertically and laterally beneath narrow rift axes. When the roof of the magma chamber ruptures because of reservoir replenishment from a buoyant melt zone near the Moho, mafic melt that has accumulated along the neutral buoyancy region (dike-gabbro boundary) starts ascending to form dike injections (Ryan, 1994). Thus, for a large, well-developed sheeted complex to form, there must be an approximate balance for an extended period between spreading rate and magma supply so that sufficient melt is available to keep pace with spreading. If the rate of spreading exceeds the rate of magma supply, the crust will be disrupted tectonically via amagmatic extension, and few or no sheeted dikes will form. If the magma supply exceeds the spreading rate, excess melt may form plutons underplating the extrusive sequence and the sheeted dikes or may cause local thickening of the crustal section by magmatic inflation.

In mid-ocean ridge environments, the rate of spreading appears to be approximately related to the rate of magma supply. Thus, fast-spreading ridges (e.g., portions of the East Pacific Rise) produce voluminous magma over a wide area beneath the ridge (Fig. 3A) (Phipps Morgan et al., 1994). The high magma supply rates produce an axial rift zone that is marked by the existence of a temporally continuous magma lens (Sinton and Detrick, 1992) and a topographically well-defined
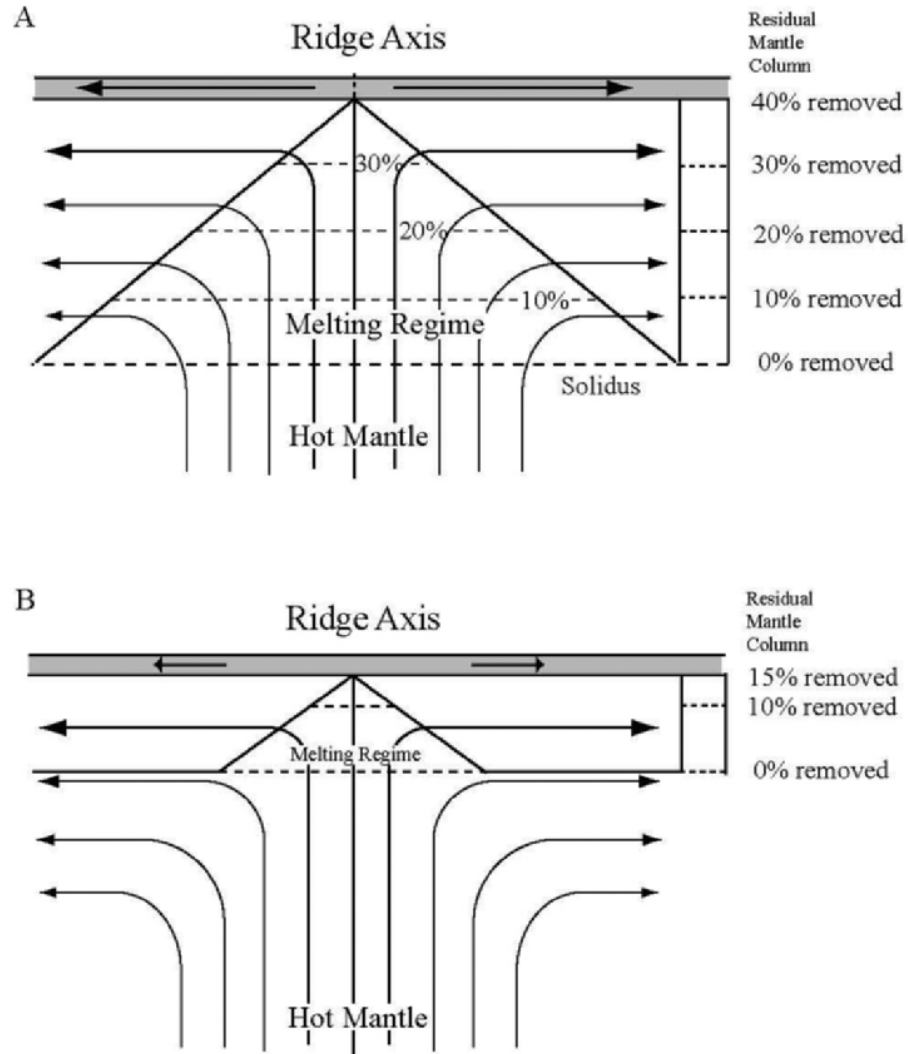

Figure 3. Melting relationships beneath fast- and slow-spreading ridges (after Malpas and Robinson, 2000). (A) Upwelling of mantle beneath a fast-spreading ridge produces partial melting over a large area and results in removal of $30 \%-40 \%$ of the mantle column, feeding large magma supply rates in a sustained mode and tempo. (B) Beneath slow-spreading axes, there is a diminished partial melting regime with removal of $10 \%-15 \%$ of the mantle column. This regime is responsible for a magma-poor spreading environment, in which magma chambers are small and ephemeral.

ridge crest reminiscent of shield volcanoes (e.g., Macdonald et al., 1993a, 1993b; Scheirer and Macdonald, 1993). On the other hand, slow-spreading ridges are associated with more restricted melting, and the magma supply is greatly reduced, creating an environment in which tectonic extension via crustal stretching and faulting predominates, so that the axial zone is marked by a deep graben. At ultraslow-spreading ridges, such as the Southwest Indian Ridge or the Gakkel Ridge, magma supply is small and episodic, and the crust is tectonically disrupted by detachment faulting, leading to exposures of the lower crust and upper mantle on the seafloor (Dick, 1989; Dick et al., 1991; Michael et al., 2003; Jokat et al., 2003).

There appears to be, therefore, an approximate balance between spreading and magma supply rates at modern midocean ridges. Such a balance is also suggested by the relatively uniform seismic thickness of in situ oceanic crust $(\sim 6 \mathrm{~km})$, although it is clear that the seismic Moho and petrologic Moho (i.e., crust-mantle lithologic boundary) do not always correlate with one another, as determined in some ophiolitic complexes (Malpas, 1973; Malpas and Stevens, 1978) and in modern oceanic lithosphere (Muller et al., 1997; McClain, 2003).

The correlation between spreading rate and magma supply at mid-ocean ridges probably reflects the relatively simple 
nature of the system. Mid-ocean ridge lavas are sourced from a dry, relatively homogeneous mantle with a constant geotherm in which melting is almost entirely dependent on decompression.

It is difficult to apply a spreading-rate-controlled model of igneous accretion to ophiolites that form in suprasubduction zone environments. In such environments, the spreading rate and magma supply are not so clearly linked. Suprasubduction zone spreading rate is controlled largely by subduction rollback, which is the major cause of lithospheric extension at a convergent plate boundary (Hamilton, 1995). The edge force of "trench suction" places the overriding lithosphere in a state of tension as the subduction zone moves oceanward under the influence of the negative buoyancy of the cold, dense descending slab. The rate of slab rollback may be related to a number of factors (see summaries by Forsyth and Uyeda, 1975; Jarrard, 1986), amongst which the most important may be the angle of subduction; steeply dipping zones such as those of the western Pacific Ocean might be expected to retreat more rapidly than the more shallow-dipping zones of the eastern Pacific (Schellart et al., 2006). The angle of subduction must itself be related to the age and density of the subducted oceanic lithosphere, with younger, hotter material being more buoyant than older, colder material (Stern and Bloomer, 1992). However, the overall rate of convergence and the absolute speed of the overriding plate (Cross and Pilger, 1982) may also be controlling factors-shallow-dipping subduction is invariably associated with high convergence rates. Whatever the specific mechanisms of subduction rollback may be, the multitude of competing forces present along a convergent margin negate the likelihood of rollback being as regular and steady-state as midocean ridge spreading.

\section{FORMATION OF SHEETED COMPLEXES}

While the rate of spreading in the upper plate within subduction environments is linked directly to the rate of subduction rollback, the magma supply rate is not. Suprasubduction zone magma supply rates are related to the local temperature profile, the lithology of the subducting crust and mantle wedge, the history and degree of melting of the mantle source, and the abundance and nature of fluids (Kincaid and Hall, 2003). The paucity of sheeted dikes in many ophiolites suggests that spreading rates in suprasubduction zone environments are commonly not matched by equal rates of magma supply. This inference is consistent with the thin nature of ophiolitic crust compared to modern oceanic crust in present-day major ocean basins (Coleman, 1977); that is, spreading in suprasubduction zones is dominated by tectonic extension, which results in crustal thinning.

Although magma supply in suprasubduction zones can be voluminous, eruptions are concentrated in the arc portions of the zones and are focused on individual volcanoes. Magma supply rates are generally lower in fore-arc and backarc regions, which are characterized by high extensional strain. These are the regions in which most ophiolites are believed to form, because ophiolites rarely contain the explosive volcanic materials characteristic of arc volcanoes.

Many ophiolites lack a coherent internal structure due to tectonic disruption during their formation and emplacement, and in some cases, pillow lavas rest directly in eruptive contact on mantle peridotites with no intervening gabbros or sheeted dikes (Dilek and Thy, 1998), a situation similar to that at modern ultraslow-spreading axes (e.g., Gakkel Ridge). In these cases, the pillow lavas must have been fed from magma sources, perhaps represented by gabbroic rocks in the mantle sequence (cf. Cannat et al., 1995), resulting in the appearance of individual dikes. Recognition of consanguineous magmatism and tectonic disruption is difficult, and synmagmatic deformation might not be as obvious as in those cases where dismemberment of the crustal sequence took place later-i.e., during emplacement of the ophiolite. The recognition of undeformed magmatic intrusions that cut deformed and extended crustal sequences in some ophiolites confirms the timing of deformation and structural omission as intra-oceanic and preemplacement on land.

\section{CONCLUSIONS}

The presence of large and well-developed sheeted dike complexes, such as those in Cyprus and Oman, is not a common feature of ophiolites. Indeed, it can be argued that the recognition of a sheeted complex should not be a requirement for the definition of this suite of rocks. The formation of a sheeted complex requires a balance between spreading rate and magma supply over a period of millions of years, a situation that is probably unusual in suprasubduction zone environments, where the two are at least partly decoupled.

Ophiolites were once considered direct analogues of oceanic lithosphere developed at mid-ocean ridges, but this view is incompatible with the geochemical characteristics of ophiolitic rocks, which indicate a strong subduction component in their melt evolution. However, it has been argued that even though ophiolites form in an anomalous spreading environment above subduction zones, they record structural and igneous processes similar to those occurring at mid-ocean spreading centers and can be considered proxies for studies of some aspects of in situ ocean crust. Such comparisons cannot be pursued too far, however. The relationship between tectonic and magmatic activities in suprasubduction spreading is controlled by different factors than those operating at mid-ocean ridge spreading centers. Care must be exercised when using features like sheeted dike complexes in ophiolites to investigate spreading processes at mid-ocean ridges.

\section{ACKNOWLEDGMENTS}

Many fruitful discussions with numerous colleagues, including R.G. Coleman, M.F.J. Flower, H. Furnes, C.A. Hopson, E.M. Moores, J.A. Pearce, J. Shervais, P. Thy, and J. Wakabayashi, have been most beneficial to our ideas presented in this paper. We especially thank John Shervais, Jeffrey Karson, and Stephen Johnston for constructive and insightful reviews that helped us improve the paper.

\section{REFERENCES CITED}

Abbott, D., and Fisk, M., 1986, Tectonically controlled origin of three unusual rock suites in the Woodlark Basin: Tectonics, v. 5, p. 1145-1160, doi: 10.1029/ TC005i007p01145.

Alabaster, T., Pearce, J.A., and Malpas, J., 1982, The volcanic stratigraphy and petrogenesis of the Oman ophiolite complex: Contributions to Mineralogy and Petrology, v. 81, p. 168-183, doi: 10.1007/BF00371294. 
Alt, J.C., Kinoshita, H., Stokking, L., and Michael, P., 1996, Proceedings of the Ocean Drilling Program, ODP Leg 148, Scientific Results: College Station, Texas, Ocean Drilling Program, 512 p.

Anonymous, 1972, Penrose field conference on ophiolites: Geotimes, v. 17, p. 24-25.

Bach, W., Erzinger, J., Alt, J., and Teagle, D., 1996, Chemistry of the lower sheeted dike complex, ODP Hole 504B: The influence of magmatic differentiation and hydrothermal alteration, in Alt, J.C., Kinoshita, H., Stokking, L., and Michael, P., Proceedings of the Ocean Drilling Program, ODP Leg 148, Scientific Results: College Station, Texas, Ocean Drilling Program, p. 39-56.

Baragar, W.R.A., Lambert, M.B., Baglow, N., and Gibson, I.L., 1989, Sheeted dikes of the Troodos ophiolite, Cyprus, in Halls, H.C., and Fahrig, W.C., eds., Mafic Dike Swarms: Geological Society of Canada Special Paper 88-9, p. 69-106.

Batanova, V.G., and Sobolev, A.V., 2000, Compositional heterogeneity in subductionrelated mantle peridotites, Troodos massif, Cyprus: Geology, v. 28, p. 55-58, doi: 10.1130/0091-7613(2000)28<55:CHISMP>2.0.CO;2.

Beccaluva, L., Coltorti, M., Giunta, G., and Siena, F., 2004, Tethyan vs. Cordilleran ophiolites: A reappraisal of distinctive tectono-magmatic features of supra-subduction complexes in relation to the subduction mode: Tectonophysics, v. 393 p. 163-174, doi: 10.1016/j.tecto.2004.07.034.

Bednarz, U., and Schmincke, H.-U., 1994, Petrological and chemical evolution of the northeastern Troodos extrusive series, Cyprus: Journal of Petrology, v. 35 p. 489-523.

Cannat, M., Mevel, C., Maia, M., Deplus, C., Durand, C., Gente, P., Agrinier, P., Belarouchi, A., Dubuisson, G., Humler, E., and Reynolds, J., 1995, Thin crust, ultramafic exposures, and rugged faulting at the Mid-Atlantic Ridge $\left(22^{\circ}-24^{\circ} \mathrm{N}\right)$ : Geology, v. 23, p. 49-52, doi: 10.1130/0091-7613(1995)023<0049:TCUEAR> 2.3.CO;2.

Church, W.R., and Riccio, L., 1974, The sheeted dike layer of the Betts Cove ophiolite complex does not represent spreading: Canadian Journal of Earth Sciences, v. 11 , p. $1499-1502$

Coleman, R.G., 1977, Ophiolites: Berlin, Springer-Verlag, 229 p.

Cross, T.A., and Pilger, R.H., Jr., 1982, Controls of subduction geometry, location of magmatic arcs, and tectonics of arc and back-arc regions: Geological Society of America Bulletin, v. 93, p. 545-562, doi: 10.1130/0016-7606(1982)93<545 COSGLO $>2.0 . \mathrm{CO} ; 2$

Detrick, R.S., Collins, J., Stephen, R., and Swift, S., 1994, In situ evidence for the nature of the seismic layer 2/3 boundary in oceanic crust: Nature, v. 370, p. 288-290, doi: 10.1038/370288a0.

Dick, H.J.B., 1989, Abyssal peridotites, very slow spreading ridges and ocean ridge magmatism, in Saunders, A.D., and Norry, M.J., eds., Magmatism in the Ocean Basins: London, Geological Society Special Publication 42, p. 71-105.

Dick, H.J.B., Schouten, H., Meyer, P.S., Gallo, D.G., Bergh, H., and Tyce, R., Patriat, P., Johnston, K.T.M., Snow, J., et al., 1991, Tectonic evolution of the Atlantis II Fracture Zone, in Von Herzen, R.P., and Robinson, P. et al, Proceedings of the Ocean Drilling Program, ODP Leg 118, Scientific Results: College Station, Texas, Ocean Drilling Program, p. 439-538.

Dilek, Y., 1998, Structure and tectonics of intermediate-spread oceanic crust drilled at DSDP/ODP Sites 504B-896A, Costa Rica Rift, in Cramp, A., Macleod, C.J., Lee, S.V., and Jones, E.J.W., eds., Geological Evolution of Ocean Basins: Results from the Ocean Drilling Program: London, Geological Society Special Publication 131, p. 179-197.

Dilek, Y., 2003, Ophiolite concept and its evolution, in Dilek, Y., and Newcomb, S. eds., Ophiolite Concept and the Evolution of Geological Thought: Geological Society of America Special Paper 373, p. 1-16.

Dilek, Y, and Flower, M.F.J., 2003, Arc-trench rollback and forearc accretion: 2. A model template for ophiolites in Albania, Cyprus, and Oman, in Dilek, Y., and Robinson, P.T., eds., Ophiolites in Earth History: London, Geological Society Special Publication 218, p. 43-68.

Dilek, Y., and Thy, P., 1998, Structure, petrology, and seafloor spreading tectonics of the Kizildag ophiolite (Turkey), in Mills, R., and Harrison, K., eds., Modern Ocean Floor Processes and the Geological Record: London, Geological Society Special Publication 148, p. 43-69.

Dilek, Y., Thy, P., and Moores, E.M., 1991, Episodic dike intrusions in the northwestern Sierra Nevada, California: Implications for multistage evolution of a Jurassic arc terrane: Geology, v. 19, p. 180-184, doi: 10.1130/0091-7613(1991)019 $<0180$ :EDIITN $>2.3$.CO;2.

Dilek, Y., Harper, G.D., Walker, J., Allerton, S., and Tartarotti, P., 1996, Structure of upper Layer-2 in Hole-896A (Leg 148), in Alt, J.A., Kinoshita, H., Stokking, L., and Michael, P.J., eds., Proceedings of the Ocean Drilling Program, ODP Leg 148, Scientific Results: College Station, Texas, Ocean Drilling Program, p. 261-279.

Dilek, Y., Moores, E.M., and Furnes, H., 1998, Structure of modern oceanic crust and ophiolites and implications for faulting and magmatism at oceanic spreading centers, in Buck, R., Karson, J., Delaney, P., and Lagabrielle, Y., eds. Faulting and Magmatism at Mid-Ocean Ridges: American Geophysical Union Monograph 106, p. 219-266.

Dilek, Y., Shallo, M., and Furnes, H., 2005, Rift-drift, seafloor spreading, and subduction zone tectonics of Albanian ophiolites: International Geology Review, v. 47, p. 147-176, doi: 10.2747/0020-6814.47.2.147.

Forsyth, D., and Uyeda, S., 1975, On the relative importance of the driving forces of plate motions: Geophysical Journal of the Royal Astronomical Society, v. 43 p. $163-200$.

Gass, I.G., 1968, Is the Troodos Massif of Cyprus a fragment of Mesozoic ocean floor?: Nature, v. 220, p. 39-42, doi: 10.1038/220039a0.
Hamilton, W.B., 1995, Subduction systems and magmatism, in Smellie, J.L., ed., Volcanism associated with extension at consuming plate margins: London, Geological Society Special Publication 81, p. 3-28.

Harper, G.D., 2003, Fe-Ti basalts in the Josephine ophiolite and propagating ridge tectonics, Klamath Mountains, California-Oregon: Geological Society of America Bulletin, v. 115, p. 771-787, doi: 10.1130/0016-7606(2003)115 $<0771$ :FBAPTI $>2.0 . \mathrm{CO} ; 2$

Hopson, C.A., Mattinson, J.M., Pessagno, E.A., and Luyendyk, B.P., 2008, California Coast Range ophiolite: Composite Middle and Late Jurassic oceanic lithosphere, in Wright, J.E., and Shervais, J.W., eds., Ophiolites, Arcs, and Batholiths: A Tribute to Cliff Hopson: Geological Society of America Special Paper 438, p. 1-101.

Ishikawa, T Nagaishi, $\mathrm{K}$, and Umino, S, 2002, Boninitic volcanism in the Oman ophiolite: Implications for thermal condition during transition from spreading ridge to arc: Geology, v. 30, p. 899-902, doi: 10.1130/0091-7613(2002)030 $<0899$ :BVITOO $>2.0$. CO; 2 .

Jarrard, R.D., 1986, Relations among subduction parameters: Reviews of Geophysics, v. 24, p. 217-284, doi: 10.1029/RG024i002p00217.

Jenner, G.A., Dunning, G.R., Malpas, J., Brown, M., and Brace, T., 1991, Bay of Islands and Little Port complexes, revisited: Age, geochemical and isotopic evidence confirms suprasubduction-zone origin: Canadian Journal of Earth Sciences, v. 28, p. 1635-1652.

Johnson, R.W., Jaques, A.L., Langmuir, C.H., Perfit, M.R., Staudigel, H., Dunkley, P.N., Chappel, B.W., Taylor, S.R., and Baekisapa, M., 1987, Ridge subduction and forearc volcanism: Petrology and geochemistry of rocks dredged from the western Solomon arc and Woodlark basin, in Taylor, N., and Exon, N.F., eds., Marine Geology, Geophysics and Geochemistry of the Woodlark BasinSolomon Islands: Circum-Pacific Council for Energy and Mineral Resources Earth Science Series, v. 7, p. 155-226.

Jokat, W., Ritzmann, O., Schmidt-Aursch, M.C., Drachev, S., Gauger, S., and Snow, J., 2003, Geophysical evidence for reduced melt production on the Arctic ultraslow Gakkel mid-ocean ridge: Nature, v. 423, p. 962-965, doi: 10.1038/ nature01706.

Karson, J.A., 1998, Internal structure of oceanic lithosphere: A perspective from tectonic windows, in Buck, R., Karson, J., Delaney, P., and Lagabrielle, Y., eds. Faulting and Magmatism at Mid-Ocean Ridges: American Geophysical Union Monograph, v. 106, p. 177-218.

Karsten, J.L., Klein, E.M., and Sherman, S.B., 1996, Subduction zone geochemical characteristics in ocean ridge basalts from the southern Chile Ridge; implications of modern ridge subduction systems for the Archean: Lithos, v. 37, p. 143-161, doi: 10.1016/0024-4937(95)00034-8.

Kidd, R.G.W., and Cann, J.R., 1974, Chilling statistics indicate an ocean-floor spreading origin for the Troodos Complex, Cyprus: Earth and Planetary Science Letters, v. 24, p. 151-155, doi: 10.1016/0012-821X(74)90020-X.

Kincaid, C., and Hall, P.S., 2003, Role of backarc spreading in circulation and melting at subduction zones: Journal of Geophysical Research, v. 108, B5, p. 2240 doi: 10.1029/2001JB001174.

Klein, E.M., and Karsten, J.L., 1995, Ocean-ridge basalts with convergent-margin geochemical affinities from the Chile Ridge: Nature, v. 374, p. 52-57, doi: 10.1038/374052a0

Macdonald, K.C., Scheirer, D.S., Carbotte, S., and Fox, P.J., 1993a, It's only topography: Part 1: GSA Today, v. 3, no. 1, p. 1, 24-25.

Macdonald, K.C., Scheirer, D.S., Carbotte, S., and Fox, P.J., 1993b, It's only topography: Part 2: GSA Today, v. 3, no. 2, p. 29-31, 34-35.

Malpas, J., 1973, A section of oceanic crust and mantle in western Newfoundland: Geological Society of America 8th Annual Northeastern Section Meeting, Abstracts and Program, v. 5, no. 2, p. 192

Malpas, J., and Langdon, G., 1984, Petrology of the upper pillow lava suite, Troodos ophiolite, Cyprus, in Gass, I.G., Lippard, S.J., and Shelton, A.W., eds., Ophiolites and Oceanic Lithosphere: London, Geological Society Special Publication 13 p. $155-167$

Malpas, J., and Robinson, P.T., 2000, Oceanic lithosphere 4. The origin and evolution of oceanic lithosphere: Magmatic processes at oceanic spreading centres: Geoscience Canada, v. 27, p. 131-146.

Malpas, J., and Stevens, R.K., 1978, Origin and emplacement of the ophiolite suite with examples from western Newfoundland: Geotectonics, v. 11, p. 453-466.

Malpas, J., Zhou, M.-F., Robinson, P.T., and Reynolds, P.H., 2003, Geochemical and geochronological constraints on the origin and emplacement of the Yarlung Zangbo ophiolites, Southern Tibet, in Dilek, Y., and Robinson, P.T., eds., Ophiolites in Earth History: London, Geological Society Special Publication 218 , p. 191-206.

McClain, J.D., 2003, Ophiolites and the interpretation of marine geophysical data: How well does the ophiolite model work for the Pacific Ocean crust?, in Dilek Y., and Newcomb, S., eds., Ophiolite Concept and the Evolution of Geological Thought: Geological Society of America Special Paper 373, p. 173-185.

McCulloch, M.T., and Cameron, W.E., 1983, Nd-Sr isotopic study of primitive lavas from the Troodos ophiolite, Cyprus: Evidence for a subduction related setting: Geology, v. 11, p. 727-731, doi: 10.1130/0091-7613(1983)11<727:NISOPL> 2.0.CO;2.

Michael, P.J., Langmuir, C.H., Dick, H.J.B., Snow, J.E., Goldstein, S.L., Graham, D.W., Lehnert, K., Kurras, G., Jokat, W., Mühe, R., and Edmonds, H.N., 2003, Magmatic and amagmatic seafloor spreading at the slowest mid-ocean ridge: Gakkel Ridge, Arctic Ocean: Nature, v. 423, p. 956-961, doi: 10.1038/nature01704. 
Moores, E.M., 1982, Origin and emplacement of ophiolites: Reviews of Geophysics, v. 20, p. 735-760, doi: 10.1029/RG020i004p00735.

Muller, M.R., Robinson, C.J., Minshull, R.S., and Bickle, M.J., 1997, Thin crust beneath Ocean Drilling Program Borehole 735B at the Southwest Indian Ridge?: Earth and Planetary Science Letters, v. 148, p. 93-107, doi: 10.1016/S0012821X(97)00030-7.

Nicolas, A., Boudier, F., and Meshi, A., 1999, Slow spreading accretion and mantle denudation in the Mirdita ophiolite (Albania): Journal of Geophysical Research, v. 104, p. 15,155-15,167, doi: 10.1029/1999JB900126.

Pearce, J.A., 1982, Trace element characteristics of lavas from destructive plate boundaries, in Thorpe, R.S., ed., Andesites: Orogenic Andesites and Related Rocks: Chichester, UK, John Wiley and Sons, p. 525-548.

Pearce, J.A., 2003, Supra-subduction zone ophiolites: The search for modern analogues, in Dilek, Y., and Newcomb, S., eds., Ophiolite Concept and the Evolution of Geological Thought: Geological Society of America Special Paper 373, p. 269-293.

Perfit, M.R., Langmuir, C.H., Baekisapa, M., Chappell, B.W., Johnson, R.W., Staudigel, H., and Taylor, S.R., 1987, Geochemistry and petrology of volcanic rocks from the Woodlark Basin: Addressing questions of ridge subduction, in Taylor, B., and Exon, N.F., eds., Marine Geology, Geophysics and Geochemistry of the Woodlark Basin-Soloman Islands: Circum-Pacific Council for Energy and Mineral Resources, Houston, Texas, Earth Science Series, v. 7, p. 113-154.

Phipps Morgan, J., Harding, A., Orcutt, J., Kent, G., and Chen, Y.J., 1994, An observational and theoretical synthesis of magma chamber geometry and crustal genesis along a mid-ocean ridge spreading center, in Ryan, M.P., ed., Magmatic Systems: San Diego, California, Academic Press, p. 139-178.

Robinson, P.T., and Malpas, J., 1990, The Troodos ophiolite of Cyprus: New perspectives on its origin and emplacement, in Malpas, J., Moores, E.M., Panayiotou, A., and Xenophontos, C., eds., Ophiolites: Oceanic Crustal Analogues: Nicosia, Cyprus, Geological Survey Department, p. 13-36.

Robinson, P.T., Melson, W.G., O'Hearn, T., and Schmincke, H.-U., 1983, Volcanic glass compositions of the Troodos ophiolite, Cyprus: Geology, v. 11, p. 400-404, doi: 10.1130/0091-7613(1983)11<400:VGCOTT>2.0.CO;2.

Ryan, M.P., 1994, Neutral-buoyancy controlled magma transport and storage in mid-ocean ridge magma reservoirs and their sheeted-dike complex: A summary of basic relationships, in Ryan, M.P., ed., Magmatic Systems: San Diego, California, Academic Press, p. 97-138.

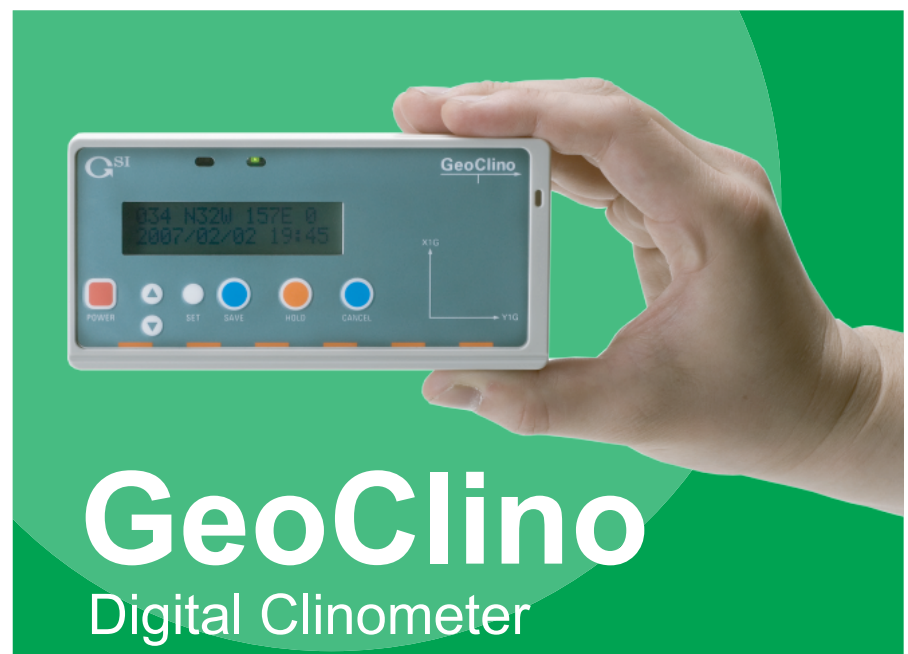

\section{Change}

your knowledge about clinometers
Scheirer, D.S., and Macdonald, K.C., 1993, Variation in cross-sectional area of the axial ridge along the East Pacific Rise: Evidence for the magmatic budget of a fast-spreading center: Journal of Geophysical Research, v. 98, p. 7871-7885, doi: 10.1029/93JB00015.

Schellart, W.P., Lister, G.S., and Toy, V.G., 2006, A Late Cretaceous and Cenozoic reconstruction of the Southwest Pacific region: Tectonics controlled by subduction and slab rollback processes: Earth-Science Reviews, v. 76, p. 191233, doi: 10.1016/j.earscirev.2006.01.002.

Searle, M.P., and Cox, J.S., 1999, Tectonic setting, origin, and obduction of the Oman ophiolite: Geological Society of America Bulletin, v. 111, p. 104122, doi: 10.1130/0016-7606(1999)111<0104:TSOAOO>2.3.CO;2.

Shervais, J.W., 1982, Ti-V plots and the petrogenesis of modern and ophiolitic lavas: Earth and Planetary Science Letters, v. 59, p. 101-118, doi: 10.1016/0012-821X(82)90120-0.

Shervais., J.W., 2001, Birth, death and resurrection: The life cycle of suprasubduction zone ophiolites: Geochemistry, Geophysics, Geosystems, v. 2, no. 1, 1010, doi: 10.1029/2000GC000080.

Shervais, J.W., and Kimbrough, D.L., 1985, Geochemical evidence for the tectonic setting of the Coast Range Ophiolite: A composite island arc-oceanic crust terrane in western California: Geology, v. 13, p. 35-38, doi: 10.1130/00917613(1985) $13<35$ :GEFTTS $>2.0 . C O ; 2$.

Shervais, J.W., Kimbrough, D.L., Renne, P., Murchey, B., and Hanan, B.B., 2004, Multi-stage origin of the Coast Range Ophiolite, California and Oregon: Implications for the life cycle of supra-subduction zone ophiolites: International Geology Review, v. 46, p. 289-315, doi: 10.2747/00206814.46.4.289

Sinton, J.M., and Detrick, R.S., 1992, Mid-oceanic ridge magma chambers: Journal of Geophysical Research, v. 97, p. 197-216, doi: 10.1029/91JB02508.

Stern, R.J., and Bloomer, S.H., 1992, Subduction zone infancy: Examples from Eocene Izu-Bonin-Mariana and Jurassic California arcs: Geological Society of America Bulletin, v. 104, p. 1621-1636, doi: 10.1130/0016-7606(1992) $104<1621$ :SZIEFT $>2.3$. CO; 2 .

Stewart, M.A., Klein, E.M., and Karson, J.A., 2002, The geochemistry of dikes and lavas from the north wall of the Hess Deep Rift: Insights into the four-dimensional character of crustal construction at fast-spreading midocean ridges: Journal of Geophysical Research, v. 107, 2238, doi: 10. 1020/2001JB000545.

Stewart, M.A., Klein, E.M., Karson, J.A., and Brophy, J.G., 2003, Geochemical relationships between dikes and lavas at the Hess Deep Rift: Implications for magma eruptibility: Journal of Geophysical Research, v. 108, 1029, doi: 10. 1029/2001JB001622.

Strong, D.F., and Malpas, J., 1975, The sheeted dike layer of the Betts Cove ophiolite complex does not represent spreading: Further discussion: Canadian Journal of Earth Sciences, v. 12, p. 894-896.

Sturm, M.E., Klein, E.M., Karsten, J.L., and Karson, J.A., 2000, Evidence for subduction-related contamination of the mantle beneath the southern Chile Ridge: Implications for ambiguous ophiolite compositions, in Dilek, Y., Moores, E.M. Elthon, D., and Nicolas, A, eds., Ophiolites and Oceanic Crust: New Insights from Field Studies and the Ocean Drilling Program: Geological Society of America Special Paper 349, p. 13-20.

Suhr, G., and Edwards, S.J., 2000, Contrasting mantle sequences exposed in the Lewis Hills massif: Evidence for the early, arc-related history of the Bay of Islands ophiolite, in Dilek, Y., Moores, E.M., Elthon, D., and Nicolas, A., eds., Ophiolites and Oceanic Crust: New Insights from Field Studies and the Ocean Drilling Program: Geological Society of America Special Paper 349, p. 433-442.

Umino, S., Miyashita, S., Hotta, F., and Adachi, Y., 2003, Along-strike variation of the sheeted dike complex in the Oman Ophiolite: Insights into subaxial ridge segment structures and the magma plumbing system: Geochemistry Geophysics Geosystems, v. 4, p. 8618, doi: 10.1029/2001GC000233

Varga, R.J., and Moores, E.M., 1985, Spreading structure of the Troodos ophiolite, Cyprus: Geology, v. 13, p. 846-850, doi: 10.1130/0091-7613(1985)13 $<846$ :SSOTTO $>2.0 . \mathrm{CO} ; 2$

Vine, F.J., and Matthews, D.H., 1963, Magnetic anomalies over oceanic ridges: Nature, v. 199, p. 947-949, doi: 10.1038/199947a0.

Weissel, J.K., Taylor, B., and Karner, G.D., 1982, The opening of the Woodlark Basin, subduction of the Woodlark spreading system, and the evolution of northern Melanesia since mid-Pliocene time: Tectonophysics, v. 87, p. 253-277, doi: 10.1016/0040-1951(82)90229-3.

Zhou, M.-F., Yumul, G.P., Malpas, J., and Sun, M.,2000, Comparative study of platinum-group elements in the Coto and Acoje blocks of the Zambales Ophiolite Complex, Philippines: The Island Arc, v. 9, p. 556-564, doi: 10. 1046/j.1440-1738.2000.00301.x.

Manuscript received 23 March 2007; accepted 8 July 2008.
Agency in USA:

Miners, Inc.

www.minerox.com 